\title{
Reciprocity In Book ReVIEWIng AMONG American, British and CANAdian ACA- DEMICS
}

\author{
JULIEN LARRÈGUE \\ Philippe Mongeon \\ JEAN-PhILIPPE WARREN \\ CAssidy R. Sugimoto \\ VINCENT LARIVIÈRE
}

\begin{abstract}
Books and their reviews are considered to be central to knowledge dissemination in the social sciences and humanities. Despite this perceive importance, few studies have assessed the relative importance of these document types in the dissemination of knowledge. This paper aims at better understanding the place of book reviews in the scholarly communication system and to shed light--through the analysis of books on Canada, United Kingdom and United States and their reviewers--on the international circulation of ideas in the social sciences and humanities. Based on 1,675,999 book reviews indexed in the Social Science Citation Index and Arts and Humanities Citation Index over the 19752016 period, our results show that book reviews are decreasing in importance in all disciplines - especially those where books have historically been peripheral. We also observe a high rate of homophily between reviewers and reviewed books, with researchers being primarily interested in the books that have been written by someone from their own country. Hence, despite the now widely held assumptions of the globalization of science, social science and humanities remains a highly localized activity.
\end{abstract}

Keywords: Book reviews, Social sciences, Humanities, Geography, Internationalization, Canada, United States, United Kingdom.

Résumé. Les monographies et leur comptes rendus sont considérés comme étant importants véhicules de diffusion des connaissances dans les sciences sociales et humaines. Malgré cette importance perçue, peu d'études ont mesuré l'importance relative de ces types de documents dans le processus de diffusion des connaissances. Cet article vise à mieux comprendre la place des comptes rendus de monographies dans le système de diffusion des connaissances et à révéler - à travers l'analyse des monographies sur le Canada, les États-Unis et 
le Royaume-Uni et de leurs comptes rendus - la circulation internationale des idées dans les sciences sociales et humaines. Basé sur 1,675,999 comptes rendus indexés par le Social Science Citation Index et le Arts and Humanities Citation Index au cours de la période 1975-2016, nos résultats montrent que les comptes rendus sont en décroissance dans l'ensemble des disciplines - et spécialement dans celles où ces types de documents sont plus périphériques. Nous observons également d'importants taux d'homophilie entre les auteurs des comptes rendus les nations étudiés dans les monographies, avec une majorité des comptes rendus réalisés par des auteurs venant du même pays que celui étant étudié dans la monographie. Ainsi, malgré les discours sur la globalisation de l'activité scientifique, les sciences sociales et humaines demeurent hautement localisées.

Mots clés: Critiques de livres, sciences sociales, sciences humaines, géographie, internationalisation, Canada, États-Unis, Royaume-Uni.

\section{INTRODUCTION}

B ook reviews (BRs) have historically been central vectors for the dissemination and evaluation of scientific knowledge. Generally appearing at the end of scholarly journals, they are meant to allow readers "to keep abreast of new publications they may wish to acquire and provide a forum for the peer review of new theories and ideas" (Spink et al., 1998: 364). As early as 1684, two British periodicals, Weekly Memorials and Medicina Curiosa, contained abstracts of articles and books. Hence,

"The practice of book reviewing in academia is as old as the scientific community itself. The earliest journals, commenced in the major European countries in the latter part of the seventeenth century, consisted for the most part of book notices; and Journal des Sçavans, the first periodical to provide regular information on scientific matters, was in fact composed entirely of summaries of scholarly or scientific works" (Nicolaisen, 2002: 129; see also Miranda, 1996).

Although in most disciplines books are no longer the privileged medium of scientific communication, books account for the largest share of cited references in most humanities disciplines and, to a lesser extent, in the social sciences (Larivière et al., 2006). This explains why many journals continue to publish BRs, especially in the humanities and social sciences. It is rather paradoxical that while the writing of BRs is not considered a prestigious activity and lends little symbolic capital to its authors, BRs remain a structuring exercise of academic research. Twenty years ago, Spink, Robins, and Schamber (1998) demonstrated that BRs are actually central intermediaries in the dissemination of scientific research. 
Similarly, Lindholm-Romantschuk (1998: viii) traced the effects of 1732 book reviews appearing in scholarly monographs during 1970-1990 and concluded that "[s]cholarly book reviews are significant indicators of scholarly communication and can successfully be utilized to trace the flow of information within and across knowledge domains." This can be evidenced by the high number of readers. For instance, Stowe (1991) showed that the BRs were the most read section of the Journal of American History, while Hartley (2003) made a similar observation for the British Journal of Educational Technology. More recent studies tend to confirm that books that are reviewed obtain, on average, higher citation rates than those that are not reviewed (Gorraiz and al, 2014).

Furthermore, BRs play a significant role in the emergence and resolution of scientific controversies. Studying BRs that have been published on widely read books has thus constituted a way for sociologists and historians of science to gauge the level of consensus on a given research question, and to identify the type of arguments leveled off by academics in the course of their discussions (Gingras (ed.), 2014). Investigation of the different arguments invoked by researchers - scientific, political, moral, philosophical, etc. - in the appreciation of their colleagues' work is also performed to measure the level of autonomy of the scientific field vis-à-vis the rest of society. Indeed, complete autonomy would normally lead academics to concentrate on scientific matters rather than, say, on the political or moral implications of a given thesis (Bourdieu, 2004). It is thus no surprise that books related to strong societal concerns such as race and identity may be subjected to close scrutiny and sometimes criticized on non-scientific grounds, as evidenced by the intense controversies that have surrounded the publication of books such as Martin Bernal's Black Athena (Lajeunesse, 2014) or Alice Goffman's On the Run (Portilla, 2016). Conversely, controversies that mainly focus on technical and quantified problems, such as Piketty's analysis of the evolution of the repartition of capital in the $21^{\text {st }}$ century, tend to preserve the autonomy of social scientific research as debates seem to be primarily shaped by the internal structure of the scientific field, including the division of labor between disciplines, rather than by the surrounding social context (Raoult et al., 2017).

Besides these few select publications, there is not yet a large body of literature on academic BRs. The fact that BRs are rarely cited partly explains this lack of interest. As they do not belong to the circle of more prestigious publications, they are often left to researchers of lesser status, such as doctoral or post-doctoral students. Consequently, BRs belong to the "supporting genre network" (Swales, 2000; Felber, 2000: 69) or, worst, to a second-class category of scientific literature (Riley and Spre- 
itzer, 1970) that tends to appear at the bottom of curriculum vitaes, when they are mentioned at all (East, 2011). Hence the relevance of a study that seeks to systematically analyze some of the structuring dimensions of this category of scientific evaluation and information. Among the few works on book reviews that have adopted a bibliometric standpoint, Zuccala and van Leeewen (2011) examined the use of book reviews in a research evaluation context; showing that despite receiving lower number of citations, such reviews remained important in the humanities. Zuccala et al. (2014) explored this idea further and introduced the concept of book reviews as megacitations. Other works in linguistics focused on the writing of BRs based on the language or nationality of the authors (Wang and An, 2013, Suárez and Moreno, 2008, Itakura and Tsui, 2011, Martin and White, 2005, Carvalho, 2002).

Our goal is somewhat different as we intend to shed light on the international circulation of ideas in the social sciences and humanities. To be more precise, this article investigates book reviewing in the social sciences and humanities over 42 years (1975-2016) using bibliometric methods and data drawn from an extended version of the Web of Science. BRs indicate a certain sense of research, of what is valued, of what is considered worthy of being discussed by the scholarly community. They offer, as a whole, a certain image of the networks that cross disciplines and the issues that drive them (Hyland, 2000). Since they have the dual function of describing the content of the books and evaluating their contribution (in terms of theory, method, sources, etc.), they serve as gatekeepers and censors for positioning the researchers in their respective field (Salager-Meyer and Alcaraz Ariza, 2004). In this context the question of indexicality represent a crucial aspect of the work of the book reviewers. They must decide what belongs (and, conversely, what does not belong) to the "geography" of their domain of research, on the metaphorical, disciplinary, and geographic levels. It seems intuitive that this separation according to "geography" will be more sensitive as one gets closer to the humanities, where the objects of study tend to be more contingent and contextualized, than in the pure and applied sciences, where objects tend to be more universal.

This paper is not the first to investigate the circulation of ideas between countries and the importance of language and national contexts in humanistic and social scientific research (Bourdieu, 2002; Gingras, 2002; Mosbah-Natanson and Gingras, 2014) or the geography and cultural territories of disciplines (Gieryn, 1999). In 1888, Louis Pasteur famously stated that "if science has no country, the scientist should have one." While devoid of any sociological conceptualization, this observa- 
tion is most illuminating and perfectly illustrates the fact that the scientific field is not international to begin with. As Bourdieu (2002: 3) puts it,

"On croit souvent que la vie intellectuelle est spontanément internationale. Rien n'est plus faux. La vie intellectuelle est le lieu, comme tous les autres espaces sociaux, de nationalismes et d'impérialismes, et les intellectuels véhiculent, presque autant que les autres, des préjugés, des stéréotypes, des idées reçues, des représentations très sommaires, très élémentaires, qui se nourrissent des accidents de la vie quotidienne, des incompréhensions, des malentendus, des blessures (celles par exemple que peut infliger au narcissisme le fait d'être inconnu dans un pays étranger) ${ }^{1}$."

Rather, globalization is a historical, contingent process that is susceptible to vary across time and place, as evidenced by the evolution in linguistic homogenization from the Middle Ages to the very end of the 20th century, from the decline of Latin to the growing domination of English (Gingras, 2002: 38). Last but not least, the mere existence of a circulation of ideas across countries does not mean that there is an 'unfiltered' international scientific or intellectual field. Indeed, foreign texts and authors are often reinterpreted and understood in light of the local context and thus subjected to a cultural translation that ascribe them a new meaning (Bourdieu, 2002: 4), as can be illustrated at one extreme by the recuperation of Greek philosophy by Nazi thinkers (Chapoutot, 2017). One, therefore, needs to pay particular attention to the power dynamics that exist within the scientific field and which assign priority to certain works on the basis of the geography or nationality of the research.

\section{Methods}

To understand the evolution of the importance of book reviews in the scholarly communication ecosystem of the social sciences and humanities, we retrieved data from the Social Science Citation Index and the Arts and Humanities Citation Index (produced by the firm Clarivate Analytics) for the 1975-2016 period (42 years of data). These databases index scholarly papers published, which includes book reviews in

1. Our translation: "We often think that intellectual life is spontaneously international. Nothing could be more wrong than this. Intellectual life is the locus, like all other social spaces, of nationalisms and imperialism, and intellectuals convey, almost as much as anyone else, prejudices, stereotypes, received ideas, and very synoptic and elementary representations that feed from accidents of daily life, of incomprehensions, misunderstandings, and wounds (such as those that may hurt narcissisms if one is unknown in a foreign country)." 
addition to standard journal articles, editorials, letters to the editor, etc. Throughout the period studied, 1,675,999 book reviews were indexed, which account for $30.1 \%$ of the $5,419,013$ documents included in the two databases. The discipline and speciality journal classification here is that of the National Science Foundation.

Two geographic variables were compiled: the country of the author of the book review, and the country of the topic of the book. Those were limited to Canada, the United States, and the United Kingdom, leaving provinces, states or cities for future research. While the country of the author of the book review comes from the affiliation field of the database (in most cases, the author's university), the country of the topic of the book was drawn from the analysis of the title of the book, using multiple keywords (see Table 1). This can only be performed for a subset of book reviews - those that have a clear nation of focus in their title. Therefore, a limitation of our analysis is that it is confined to books that could be ascribed to a given country on the basis of their title alone. Although many books focusing on specific regions do not indicate in their titles their geographic loci, our pool of BRs is substantial enough to offer a stimulating account of certain global tendencies.

Table 1. Country of book topic, associated keywords, and number of book reviews

\begin{tabular}{|c|c|c|c|c|c|}
\hline & \multicolumn{3}{|c|}{ Country of book topic } & \multirow{2}{*}{$\begin{array}{r}\text { Share of } \\
\text { book reviews }\end{array}$} \\
\hline & & Canada & $\begin{array}{r}\text { United } \\
\text { Kingdom }\end{array}$ & $\begin{array}{r}\text { United } \\
\text { States }\end{array}$ & \\
\hline \multirow{4}{*}{ 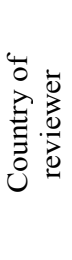 } & Canada & $74.9 \%$ & $6.5 \%$ & $4.4 \%$ & $6.7 \%$ \\
\hline & United Kingdom & $5.2 \%$ & $44.0 \%$ & $8.5 \%$ & $18.7 \%$ \\
\hline & United States & $15.7 \%$ & $37.9 \%$ & $81.7 \%$ & $58.6 \%$ \\
\hline & Other & $4.5 \%$ & $11.9 \%$ & $5.6 \%$ & $16.0 \%$ \\
\hline
\end{tabular}

Note: We didn't use the keyword "US" to avoid catching false positives with the word "us". We also excluded the keyword "English" because it may often refer to the language and not the country. We also excluded book titles referring to South or Latin America because these countries are not included in this study, but also book titles referring to North America because of their imprecision. 


\section{The Decline of Book Reviews Across Disciplines}

Once central in the scientific production of humanities and arts, and to a lesser extent in the social sciences, BRs have gradually lost ground to papers or conference abstracts. Four main reasons behind this decline can be inferred from the literature: the specialization of research (Jones, 2011), the exponential growth of research articles (Bornmann and Mutz, 2014) and the corresponding relative decline of books (Greco and Spendley, 2016), as well as the appearance of new digital aggregators that reduce the need for syntheses (Lindholm-Romantschuk, 1998). "In the days of printed texts," remarked Hartley, "book review editors and their reviewers exerted considerable influence over who read what, where, and when. Perhaps this influence is waning in today's electronic world simply because so much is now available?" (Hartley, 2006: 1205). The areas that are closer to the pure and applied sciences have been more affected by this evolution than those that neighbor the humanities, to the point that it may be possible, following Hartley (2006), to draw out a map of disciplines according to BRs' usefulness for scholars and the regularity with which they read them. As one may have guessed, BRs are generally more valued in the humanities and social sciences than they are in the pure and applied sciences. And within the humanities and social sciences, disciplines that have adopted the scientific model of the pure and applied sciences rely less on BRs than the ones that are less normalized and paradigmatic-like (Kuhn, 1962).

This can be demonstrated by focusing on the importance of BRs across the social sciences and humanities. Figure 1 shows the proportion of BRs out of all documents published, by discipline. One can clearly see how the proportion of BRs varies sharply from one discipline to another, with percentages going from $3 \%$ in psychology to $68 \%$ in history for the 1998-2016 period. We also observe a clear divide between pure and applied fields of research. As expected, disciplines such as history, religion, and literature boast a larger proportion of BRs in the database than fields that are closely related to specific professions, such as social work, management, criminology, economics and psychology. As is often the case, sociology stands at the crossroads of these two archetypes. If we were to take the entire pool of available sociology publications in the database (1996-2016), the proportion of BRs would be close to $40 \%$, which is lower than history $(70 \%)$ but higher than what we can find in more applied disciplines such as management (10\%). Hence, when it comes to BRs, sociology once again occupies a middle ground of sort in the realm of social sciences, combining scientific and literary traditions (Nisbet, 1976; Lepenies, 1988; Sugimoto et al., 2016). 
Figure 1. Proportion of book reviews out of all documents published, by discipline, 1975-2016

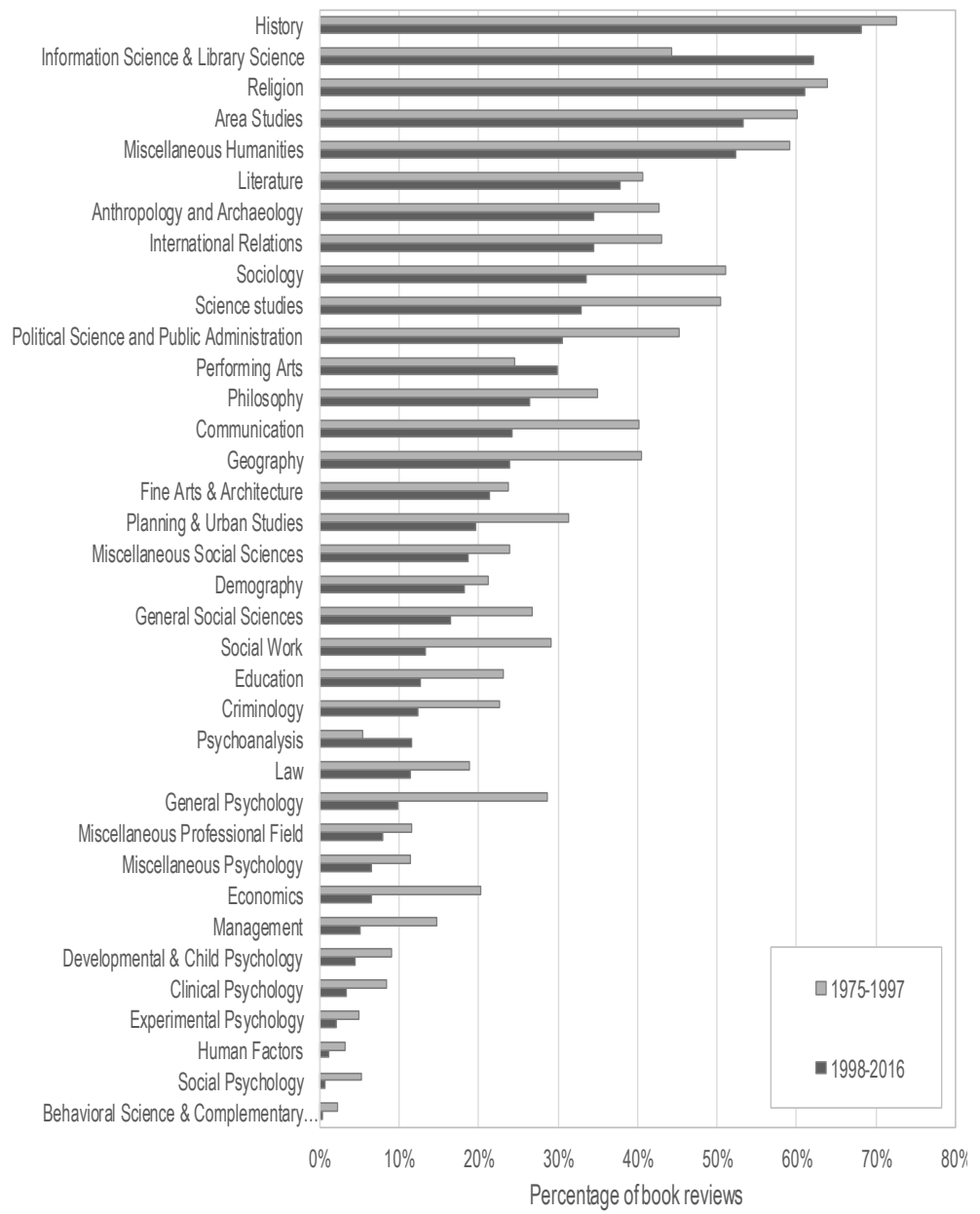

Another important finding is that we observe a clear, general decline in the publication of BRs over time. This decline has been especially sharp for disciplines such as law, most likely because of the four reasons cited above (specialization, accelerated growth of articles and the corresponding decline of books, electronic accessibility of sources), but virtually all disciplines have been affected. The only exceptions to this trend are information / library sciences and performing arts, where the publication of BRs has actually increased between 1975 and 2016. Noticeably, even 
disciplines where books assume a pivotal role have been affected by this declining trend, albeit to a lesser extent. For instance, in history, book reviews make up $68 \%$ of all publications for the 1998-2016 period, against 73\% for 1975-1997. BRs in sociology have also experienced a steep reduction. Half of publications in sociology journals used to be BRs up to 1995; they have been reduced by half in the last twenty years and now stand at roughly $25 \%$. In other words, as of 2016 , one out of four publications in sociology journals are BRs (although, because of their length, they comprise a small portion of the journals themselves). This is consistent with the fact that since the 1980s, books are less and less cited in scientific literature all disciplines combined, though their use remains central in disciplines such as history or literature (Larivière et al., 2006).

We already mentioned that the decline of book reviews can be partly attributed to the decline of books themselves. If fewer books are published, then there are mechanically less books to review. But the decline in the publication of books is itself a product of the declining value of book publishing in the vast majority of fields. Indeed, books today afford their authors less scientific and symbolic credit than they used to do. As articles, once considered units of knowledge, progressively became "accounting units" used to evaluate scientists themselves (Gingras, 2018), books became less important in the academic ecology. The fact that books are considered less important for the transmission of ideas might thus partly explain the fact that academics write less book reviews than they used to do. Indeed, as we underlined in the introduction, writing a book review is not only a material operation but carries with it a symbolic meaning. On the semiotic level, publishing an analysis of a book implies that this work is worth being discussed, either for positive or negative reasons. If books are less central in research in general, both materially (because they are less written) and symbolically (because they are less cited), they might also be considered less worth considering and spending time on, and hence less published and cited, and so on. It seems evident that these dynamics are at play here.

\section{Who Reviews What? Homophily Between Reviewers and REVIEWED BooKs}

Now that we have established a decline in the (numerical and symbolic) importance of book reviews in the social sciences and humanities, we can turn to the question of the geographic circulation of ideas. Is there a homophily between the topic of books and the reviewers' countries? How does the relationship between the book topics and their reviewers vary 
across disciplines and over time? To explore this dimension, we ascribed a country to each of the reviewed books of our database (see methods). To neutralize the effects of language on the circulation of ideas (or lack thereof), we focus on three predominantly English-speaking countries, namely the United States, Canada, and the United Kingdom. Though the numbers of books successfully categorized as focusing on a country is quite important $(124,874$ for the US, 63,439 for the UK and 15,007 for Canada), the findings must still be carefully interpreted as they exclude the majority of books whose topics could not be ascribed to any of the three countries studied.

Figure 2 shows the proportion of books reviewed from authors belonging to the same country as the books' topic, by discipline. A striking finding concerns the important differences between the United States, Canada, and the United Kingdom. Comparatively to the United Kingdom and Canada, books mentioning the United States in their titles are much more likely to be reviewed by a researcher from this same country. It is also worth underlining that this result is constant across disciplines, from library and information science (97\%) to law (93\%), to social work (92\%), communication (91\%), history (84\%) and philosophy (80\%). In fact, in all disciplines, the proportion of books written about the US and reviewed by US authors is systematically higher than $50 \%$, with most disciplines being higher than $75 \%$. The prestige of their institutions, the quality and quantity of their resources, and the sheer number of their researchers facilitate the recruitment of book reviewers from their own country.

The situation is very different in the UK and Canada. For books about the UK, a reviewer is generally much less likely to also be from the UK - although we can observe important oscillations from one discipline to another. While certain areas of research, including performing arts (34\%), literature (29\%) and information science (22\%) are highly heterophilic, others stand much closer to the US model, with high rates of homophily between the country of the books' topics and reviewers. In the latter category, we can mention the cases of planning and urban studies $(85 \%)$, geography $(79 \%)$, or criminology $(74 \%)$. Canada occupies a middle-ground position between the United States and the United Kingdom. It is not as autonomous as the US, yet not as open as the UK. Interestingly, books about Canada in political science ( $87 \%)$ and sociology (74\%) are more likely than books in law (70\%) and economics (64\%) to be reviewed by Canadian authors. 
Figure 2. Proportion of books reviewed by authors belonging to the same country of book's topic, by discipline

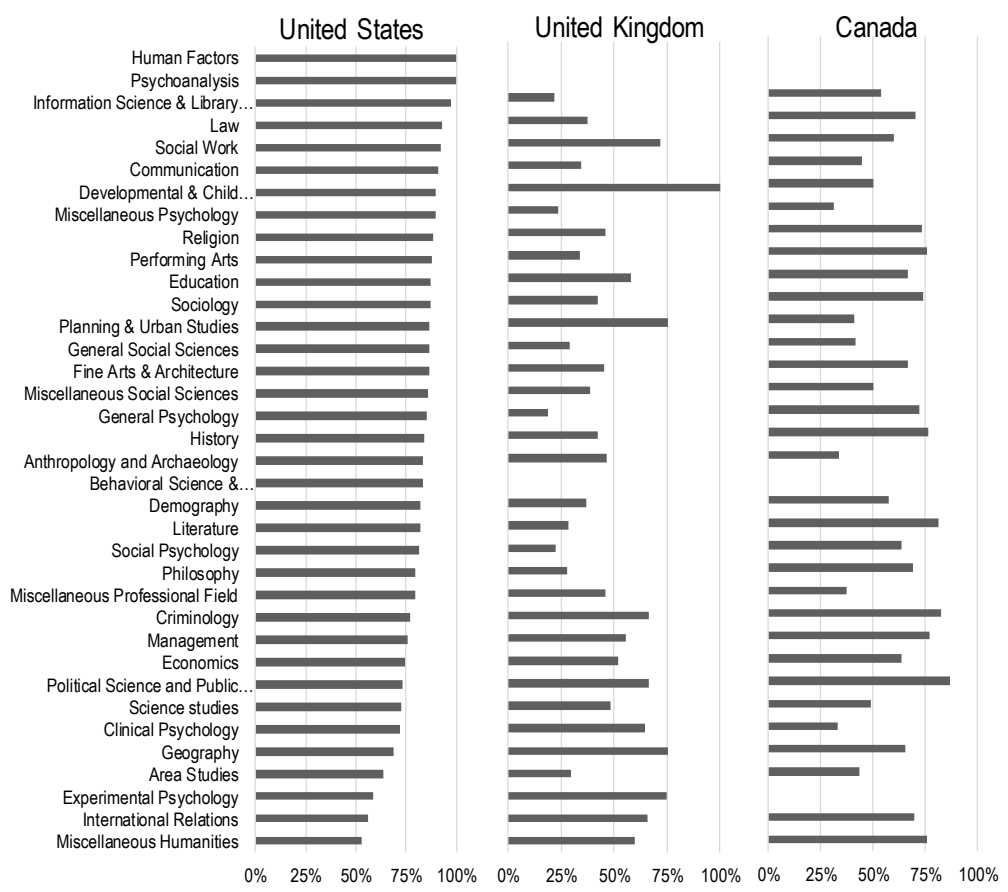

Such trends are, in some cases, evolving over time. Figure 4 presents the overall proportion of book focusing on a country which is also reviewed by researchers from the same country. On the whole, the trends observed by discipline are observed at the macro level, with a higher proportion of books on the United States being reviewed by American researchers, followed by books about Canada reviewed by Canadians, and then British by British. Quite striking is the stability of the pattern for the United States: throughout the period, the percentage of homophily oscillates between $80 \%$ and $90 \%$, and has been remarkably stable at about $85 \%$ since the early 1990s. In the case of Canada, we observe a decrease in homophily, from about $70 \%$ in the early 1980 s to slightly less than $60 \%$ in 2016. For the United Kingdom, we observe an opposite pattern: while about one-third of manuscripts on the country had reviewers from the same country in 1975, this percentage increased to 50\% in 2016. 
Figure 3. Evolution of the homophily between book topics and the country of the reviewer, 1975-2016.

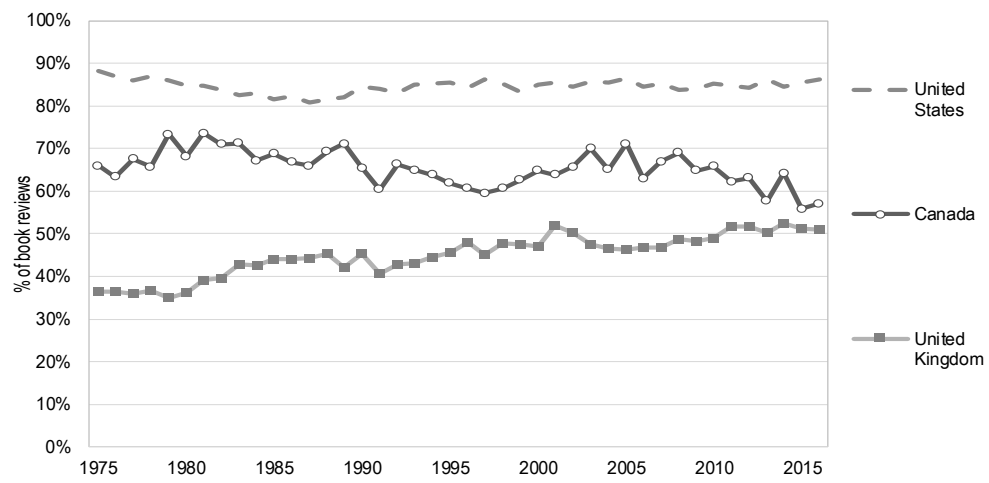

The social hierarchies between the three countries can be further documented by focusing on the directions of the circulation of ideas. Indeed, as relational aspects play a pivotal role in symbolic inequalities, one can legitimately wonder to what extent are American researchers interested in foreign topics in comparison to British and Canadian ones? Following the sociological rule that dominant entities tend to give little attention to dominated ones (Bourdieu, 1984; Fourcade et al., 2015), one could predict that authors from the United States will be, on average, less interested in reviewing books that do not concern their country. Conversely, because of the relational character of social hierarchies, British and Canadian academics should be more interested than their American counterparts in reviewing foreign books, especially when they concern the United States.

Table 2, which shows the relationship between the country of book reviewers and that of book topics, tend to confirm these hypotheses, especially when it comes to the United States-Canada relationship. Indeed, while $74.9 \%$ of the books concerning Canada have been reviewed by Canadian authors, $15.7 \%$ of these have been reviewed by American authors, and $5.2 \%$ by British authors. One could stop here and conclude that American academics are more opened to foreign topics than hypothesized. In fact, this finding must be put in perspective as the share of book reviews is not the same for American, British and Canadian academics. For instance, while Canadian authors have only reviewed $4.4 \%$ of the books concerning the United States, they also only wrote $6.7 \%$ of the BRs referenced in the Web of Science. Put together, these findings clearly demonstrate an asymmetrical relationship between the two countries: American academics are relatively less interested in topics relating 
to Canada than Canadian academics are interested in American affairs. While similar, the pattern is more balanced than one could have expected when it comes to the relationship between the United States and United Kingdom. Indeed, American authors make up approximately one fifth (37.9\%) of the book reviews concerning the United Kingdom, while the British account for $44.0 \%$ of reviews of books on the same country, which is quite low when compared with the rate of homophily among Canadian and American academics (74.9\% and 81.7\% respectively).

Table 2. Distribution of the country of book reviewers by country of book topics, 1975-2016

\begin{tabular}{|c|c|c|c|c|c|}
\hline & \multicolumn{3}{|c|}{ Country of book topic } & \multirow{2}{*}{$\begin{array}{r}\text { Share of } \\
\text { book reviews }\end{array}$} \\
\hline & & Canada & $\begin{array}{r}\text { United } \\
\text { Kingdom }\end{array}$ & $\begin{array}{r}\text { United } \\
\text { States }\end{array}$ & \\
\hline \multirow{4}{*}{ 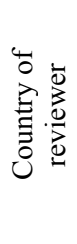 } & Canada & $74.9 \%$ & $6.5 \%$ & $4.4 \%$ & $6.7 \%$ \\
\hline & United Kingdom & $5.2 \%$ & $44.0 \%$ & $8.5 \%$ & $18.7 \%$ \\
\hline & United States & $15.7 \%$ & $37.9 \%$ & $81.7 \%$ & $58.6 \%$ \\
\hline & Other & $4.5 \%$ & $11.9 \%$ & $5.6 \%$ & $16.0 \%$ \\
\hline
\end{tabular}

\section{Book Reviewing and the Unequal Structure of the Scientific Field: Explaining United States' Autarky}

How then can we explain these important variations between countries? A plausible explanation for the UK results might be the global interest in topics related to the UK, the emergence of a European research community that encourages the recruitment of reviewers from other European countries, as well as the constitution of international networks within the Commonwealth countries (including Canada) and with the US. It is indeed undeniable that there exist strong connections between the scholars of the three countries analyzed. The low proportion of books reviewed from authors of the same country in British literature, philosophy and law journals, might thus be attributed to these privileged relationships. But this explanation is not entirely convincing. If the results were truly attributable to an invisible college of English-speaking scholars, then why is the United States' rate of homophily so high? One should thus rather interpret these findings in light of the structure and functioning of the scientific field. To quote Bourdieu (1975: 19), "The 'pure' uni- 
verse of even the 'purest' science is a social field like any other, with its distribution of power and its monopolies, its struggles and strategies, interests and profits." Inequalities not only exist between individual scientists, departments and universities, but also at the country and regional levels. Indeed, while certain countries such as the United States occupy dominant positions, others, including the United Kingdom and Canada, are relatively more peripheral (while occupying on the global stage a relatively dominant position).

While it might at first seem counter-intuitive that dominant entities are more autarkic-like than peripheral ones, it is in fact a common feature of social fields that produce symbolic goods, from culture (Bourdieu, 1984) to science (Bourdieu, 2004). This correlation between domination and autarky has been well exposed in the case of economics, a discipline that is highly prestigious in the social sciences and public sphere and whose openness to interdisciplinary is, logically, quite limited in comparison with other disciplines such as sociology or political science (Fourcade et al., 2015; Heilbron and Bokobza, 2015). To be sure, this does not necessarily mean that autarky is the result of a conscious strategy aimed at excluding potential challengers. Indeed,

"As sociologists know well, this dynamic is characteristic of unequal situations: those in a central position within a field fail to notice peripheral actors and are also largely unaware of the principles that underpin their own domination (Bourdieu 1984). Instead they tend to rationalize power and inequality as a 'just' product of merit, justified by effort or talent" (Fourcade et al., 2015: 95).

This interpretation is further supported by the fact that our findings are perfectly congruent with those previously obtained by other scholars on the internationalization of social sciences articles across regions (Gingras and Mosbah-Natanson, 2014). As is the case for BRs, the most dominant entities, namely North America and Europe, produce the "smallest proportion of interregional collaborative articles" (Gingras and MosbahNatanson, 2014: 635). Interestingly, while both North America and Europe present similar proportions of extraneous collaborations, the actual forms of these collaborations differ. European scientists tend to collaborate with peripheral regions such as Asia or Africa more often than North American ones do, with the latter predominantly working with European scientists, that is with another dominant pole. The patterns of citations are also illuminating as they confirm the worldly domination of North America, including over Europe, and its sociological translation, namely (relative) autarky. Indeed, North American social scientists mainly cite local journals, a pattern that goes largely unchallenged by the growing 
internationalization of scientific research (Gingras and Mosbah-Natanson, 2014: 638).

\section{Conclusion}

This article was aimed at investigating the international circulation of ideas between three English-speaking majority countries, namely Canada, the United States and the United Kingdom. By focusing on book reviews, we were able to draw out the "geography of thought" (Nisbett, 2003) within the social sciences and humanities, and to complement previous analyses conducted on research articles (Gingras and MosbahNatanson, 2014). Our findings can be summarized as follow.

First, we observe a high rate of homophily between reviewers and reviewed books, with reviewers being primarily interested in the books that have been written on their own country. Hence, despite the now widely held discourses on the globalization of science, humanistic and social scientific research remains a highly localized activity. Second, the circulation of ideas between the three countries analyzed is not random but follows preexisting social hierarchies. In particular, researchers from the United States display an autarky-leaning behavior and tend to show relatively little interest in books written by researchers affiliated to foreign institutions, whereas Canadian and British academics are more opened to those. Our results also suggest that the United States' disinterest in non-American books is primarily witnessed at the authorship and institutional levels rather than at the topical level. Though our data do not cover this question, it is plausible that books authored by American academics on topics relating to foreign countries are much more likely to be reviewed by American authors than books authored by foreign academics on topics relating to the United States.

These findings tend to complexify the classical explanations given to the lack of international circulation of ideas in the social sciences and humanities. In general, historians and sociologists of science legitimately underline that in contrast to the unsituated objects analyzed in the natural and physical sciences (genes, microbes, atoms, etc.), the indexicality of objects studied in the humanities and social sciences (education, ethnicity, culture) makes it more difficult for researchers to delocalize their fieldwork and to decontextualize meaning (Gingras and MosbahNatanson, 2010, 153). Although this interpretation is clearly supported by our findings, we can also propose another complementary explanation. The case of book reviews seems to show that another important variable in the circulation of ideas is institutional homophily. More than 
the indexicality of objects, it is the national nature of scientific fields that best account for our findings (Bourdieu, 2002; Sapiro, 2014).

The indexical nature of humanistic and social scientific objects undeniably plays a role in the reinforcement of national boundaries, as autarky can then be legitimized on purely scientific grounds. Hence, rather than trying to separately gauge their respective effect, institutional homophily and topical indexicality should be viewed as highly intricated and thus almost impossible to distinguish from one another. One must thus go beyond the idealism/materialism dichotomy and acknowledge the dual nature of book reviewing to fully account for the international circulation of ideas in the humanities and social sciences.

\section{REFERENCES}

Bornmann, Lutz and Rüdiger Mutz. 2015. Growth rates of modern science: A bibliometric analysis based on the number of publications and cited references. Journal of the Association for Information Science and Technology 66 (11). 2215-2222.

Bourdieu, Pierre. 1975. The specificity of the scientific field and the social conditions of the progress of reason. Social Science Information 14 (6):19-47.

Bourdieu, Pierre. 1984. Distinction: A social critique of the judgement of taste. Cambridge, Mass: Harvard University Press.

Bourdieu, Pierre. 2002. Les conditions sociales de la circulation internationale des idées. Actes de la recherche en sciences sociales 145 (1):3-8.

Bourdieu, Pierre. 2004. Science of science and reflexivity. Cambridge: Polity.

Chapoutot, Johann. 2017. La révolution culturelle nazie. Paris: Gallimard.

De Carvalho, Gisèle. 2002. Rhetorical Patterns of Academic Book Reviews Written in Portuguese and in English. Proceedings of the 2nd International Contrastive Linguistics Conference Santiago de Compostela, 261268. Santiago de Compostela: Universidade de Santiago de Compostela.

East, John W. 2011. The scholarly book review in the humanities: An academic Cinderella? Journal of Scholarly Publishing 43 (1):52-67.

Felber, Lynette. 2002. The Book Review: Scholarly and Editorial Responsibility. Journal of Scholarly Publishing 33 (3):166-172.

Fourcade, Marion, Etienne Ollion, and Yann Algan. 2015. The superiority of economists. Journal of economic perspectives 29 (1):89-114.

Gieryn, Thomas F. 1999. Cultural boundaries of science: Credibility on the line. Chicago: University of Chicago Press. 
Gingras, Yves. 2002. Les formes spécifiques de l'internationalité du champ scientifique. Actes de la recherche en sciences sociales 141-142 (1-2):3145 .

Gingras, Yves (ed.). 2014. Controverses : Accords et désaccords en sciences humaines et sociales. Paris: Editions CNRS.

Gingras, Yves. 2018. Les transformations de la production du savoir : de l'unité de connaissance à l'unité comptable. Zilsel (2):139-152.

Gingras, Yves and Sébastien Mosbah-Natanson (dir). 2010. Where are social sciences produced? World Social Science Report. Paris: Unesco \& International Social Science Council.

Gorraiz, Juan, Christian Gumpenberger, and Philip J. Purnell. 2014. The power of book reviews: a simple and transparent enhancement approach for book citation indexes. Scientometrics 98 (2):841-852.

Greco, Albert N. and Alana M. Spendley, 2016. The Price of University Press Books, 2012-14. Journal of Scholarly Publishing, 47(2): 106-120.

Hartley, James. 2003. On the presentation of book reviews. Learned Publishing $16(3): 219-220$.

Hartley, James. 2006. Reading and writing book reviews across the disciplines. Journal of the American Society for Information Science and Technology 57 (9): 1194-1207.

Heilbron, Johan and Anaïs Bokobza. 2015. Transgresser les frontières en sciences humaines et sociales en France. Actes de la recherche en sciences sociales $210(5): 108-121$.

Hyland, Ken. 2000. Praise and Criticism: Interactions in Book Reviews. In Disciplinary Discourses: Social Interactions in Academic Writing, edited by Ken Hyland, 41-62. London: Longman.

Itakura, Hiroko and Amy B.M. Tsui. 2011. Evaluation in academic discourse: Managing criticism in Japanese and English book reviews. Journal of Pragmatics (43):1366-1379.

Jones, Benjamin F. 2009. The burden of knowledge and the "death of the renaissance man": Is innovation getting harder?. The Review of Economic Studies 76 (1): 283-317.

Kuhn, Thomas S. 1962. The Structure of Scientific Revolutions. Chicago: University Of Chicago Press.

Larivière, Vincent, Éric Archambault, Yves Gingras and Étienne Vignola-Gagné. 2006. The place of serials in referencing practices: Comparing natural sciences and engineering with social sciences and humanities. Journal of the American Society for Information Science and Technology 57 (8): 997-1004.

Lajeunesse, Maude. 2014. Identité raciale et guerres culturelles dans le champ intellectuel américain : la controverse autour de Black Athena. In Contro- 
verses : Accords et désaccords en sciences humaines et sociales, edited by Yves Gingras, 65-109. Paris: Editions CNRS.

Lepenies, Wolf. 1988. Between Literature and Science. The Rise of Sociology. Vol. 10. Cambridge: Cambridge University Press.

Martin, James R. and Peter R. White. 2005. The Language of Evaluation: Appraisal in English. London and New York: Palgrave.

Moreno, Ana I. and Lorena Suarez. 2008. A study of critical attitude across English and Spanish academic book reviews. Journal of English for Academic Purposes (7):15-29.

Mosbah-Natanson, Sébastien and Yves Gingras. 2014. The globalization of social sciences? Evidence from a quantitative analysis of 30 years of production, collaboration and citations in the social sciences (1980-2009). Current Sociology 62 (5):626-646.

Nicolaisen, Jeppe. 2002. The scholarliness of published peer reviews: a bibliometric study of book reviews in selected social science fields. Research Evaluation 11 (3):129-140.

Nisbet, Robert Alexander. 1976. Sociology as an Art Form. Piscataway. New Jersey: Transaction Publishers.

Nisbett, Richard E. 2003. The geography of thought: How Asians and Westerners think differently ... and why. New York: The Free Press.

Orteza y Miranda, Evelina. 1996. On book reviewing. Journal of Educational Thought 30 (2):191-202.

Portilla, Anna. 2016. On the Run : l'ethnographie en cavale? Genèses (1):123139.

Raoult, Sacha, Brendan Leonard, and Arnaud Derbey. 2017. A Prophet in his Hometown? The Academic Reception of Thomas Piketty's "Capital in the Twenty-First Century" Across Disciplines in France and in the United States. The American Sociologist 48 (3-4):453-475.

Riley, Lawrence E. and Elmer A. Spreitzer. 1970. Book reviewing in the social sciences. The American Sociologist (5):358-363.

Römer, Ute. 2010. Establishing the Phraseological Profile of a Text Type: The Construction of Meaning in Academic Book Reviews. English Text Construction 3 (1): 95-119.

Salager.-Meyer, Françoise. 2001. This book portrays the worst form of mental terrorism: critical speech acts in medical English book reviews. In Approaches to the Pragmatics of Scientific Discourse, edited by András Kertész, 47-72. Frankfurt am Main: Peter Lang.

Salager.-Meyer, Françoise and Maria Angeles Alcaraz-Ariza. 2004. Negative appraisals in academic book reviews: A cross-linguistic approach. In Intercultural Aspects of Specialized Communication, edited by Christopher Candlin and Maurizio Gotti, 149-172. Bern: Peter Lang. 
Sapiro, Gisèle. 2014. Le champ est-il national ? Actes de la recherche en sciences sociales 200 (5):70-85.

Snizek, William E. and Ellsworth R. Fuhrman. 1979. Some factors affecting the evaluative content of book reviews in sociology. American Sociologist 14 (1):108-114.

Spink, Amanda, David Robins, and Linda Scamber. 1998. Use of Scholarly Book Reviews: Implications for Electronic Publishing and Scholarly Communication. Journal of the American Society for Information Science XLIX (4):364-374.

Stowe, Steven. 1991. Thinking about reviews. Journal of American History 78 (2):591-595.

Suárez, Lorena and Ana I. Moreno. 2006. The rhetorical structure of academic journal book reviews: A crosslinguistic and cross-disciplinary approach. Proceedings of the 5th International AELFE Conference. Prensas Universitarias de Zaragoza.

Suárez-Tejerina, Lorena. 2005. Is evaluation structure-bound? An EnglishSpanish contrastive study of book reviews. In Strategies in academic discourse, edited by Elena Tognini-Bonelli and Gabriella Del Lungo, 117132. Philadelphia: John Benjamins Publishing Company.

Sugimoto, C.R., Sugimoto, T., Tsou, A., Milojević, S., Larivière, V. 2016. Age stratification and cohort effects in scholarly communication: A study of social sciences. Scientometrics, 109(2): 997-1016.

Swales, John. 1990. Genre Analysis: English in Academic and Research Settings. Cambridge: Cambridge University Press.

Wang, Dongmei and Xuehua An. 2013. A Study of Appraisal in Chinese Academic Book Reviews. Journal of Language Teaching and Research 4 (6):1247-1252.

Wilder, Gary. 2005. The French Imperial Nation-State: Negritude and Colonial Humanism Between the Two World Wars. Chicago: University of Chicago Press.

Zuccala, Alesia, Maarten van Someren and Maurits van Bellen. 2014. A machine-learning approach to coding book reviews as quality indicators: Toward a theory of megacitation. Journal of the Association for Information Science and Technology 65 (11): 2248-2260.

Zuccala, Alesia and Thed van Leeuwen. 2011. Book reviews in humanities research evaluations. Journal of the American Society of Information Science and Technology 62 (10): 1979-1991 
Julien Larrègue is based out of the École de bibliothéconomie et des sciences de l'information, Université de Montréal, and Observatoire des Sciences et des Technologies, Centre Interuniversitaire de Recherche sur la Science et la Technologie, Université du Québec à Montréal.

Philippe Mongeon is based at the École de bibliothéconomie et des sciences de l'information, Université de Montréal and the Danish Centre for Studies in Research and Research Policy, Aarhus University, Aarhus, Denmark.

Jean-Philippe Warren is based at Concordia University, Montréal.

Cassidy R. Sugimoto is at the School of Informatics and Computing, Indiana University, Bloomington.

Vincent Larivière is based at the École de bibliothéconomie et des sciences de l'information, Université de Montréal, and Observatoire des Sciences et des Technologies, Centre Interuniversitaire de Recherche sur la Science et la Technologie, Université du Québec à Montréal. 